\title{
Calcium Signaling
}

\section{Martin D. Bootman}

The Babraham Institute Babraham Research Campus, Cambridge CB22 3AT, United Kingdom

Correspondence: martin.bootman@bbsrc.ac.uk

Calcium ions regulate processes as diverse as cell motility, gene transcription, muscle contraction, and exocytosis (Berridge et al. 2000). The first realization that they are critical for cellular function is often attributed to Sydney Ringer, who discovered in 1883 that saline solution made up using London tap water (which contained calcium) supported the contraction of isolated frog hearts, whereas saline made up using distilled water (which lacked calcium) could not. Subsequent work revealed that numerous cell biological processes are controlled by calcium (Carafoli

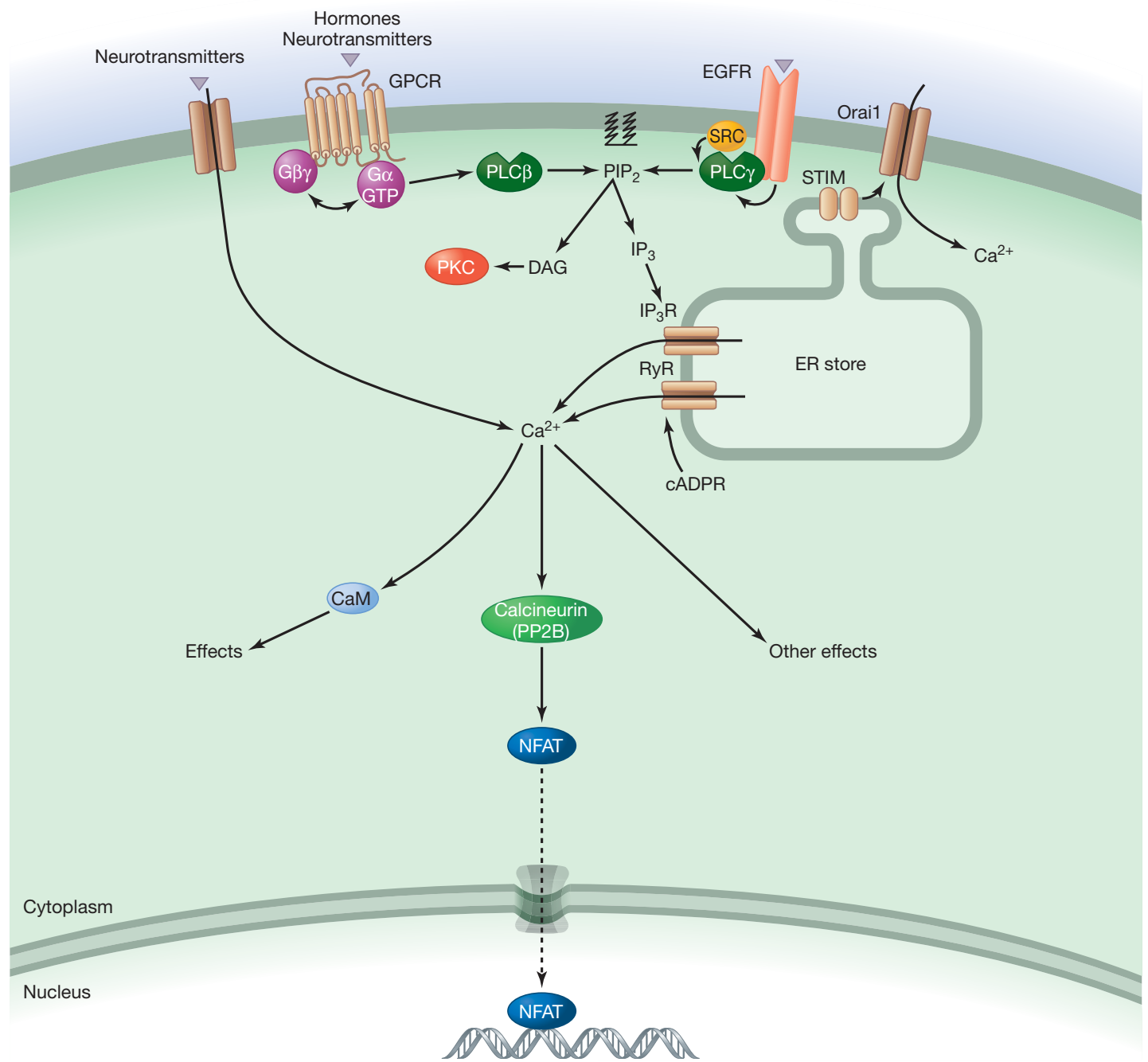

Figure 1. Calcium signaling (simplified view). 


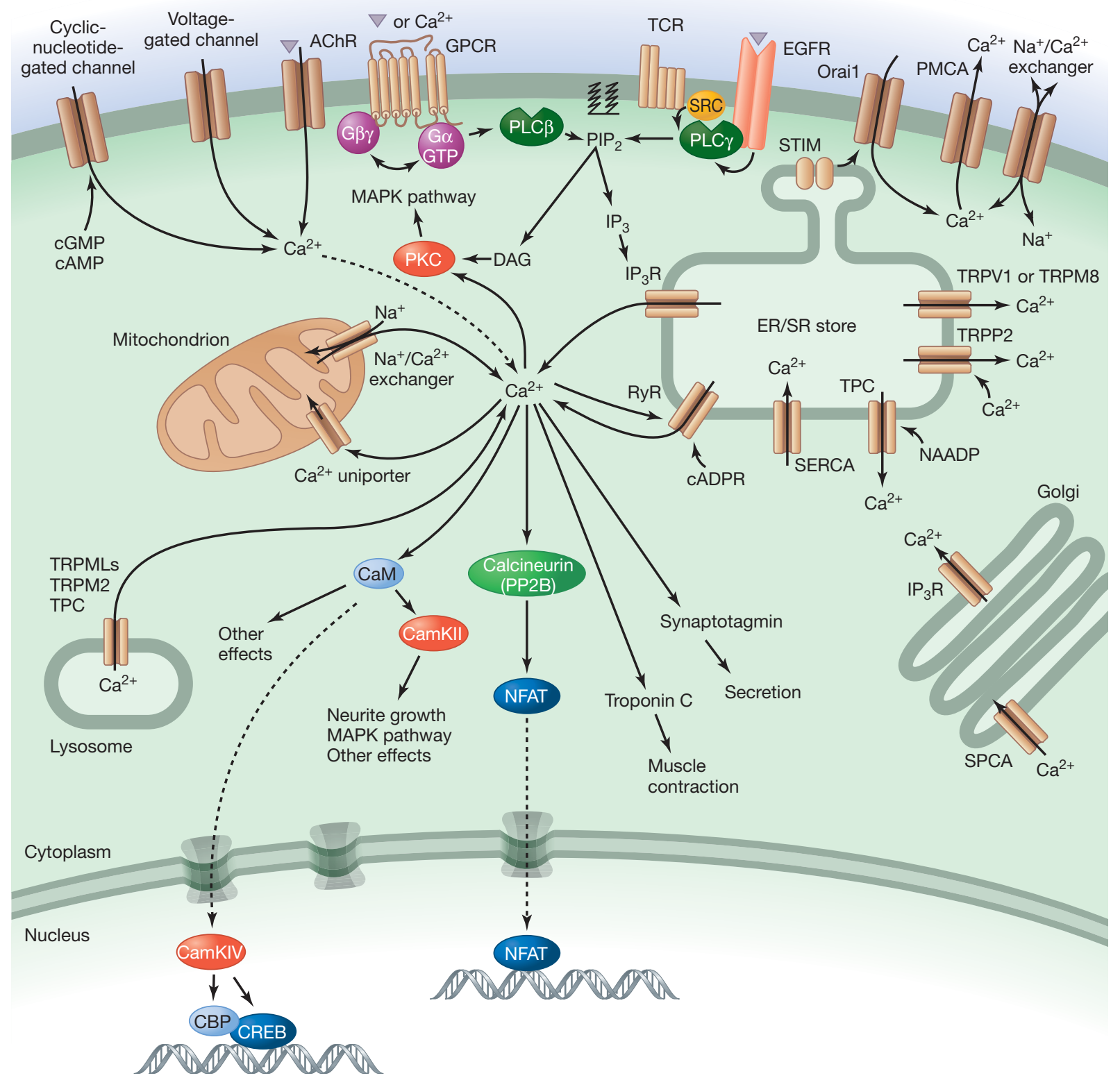

Figure 2. Calcium signaling.

2003). Particularly important was the discovery in the 1950s that calcium triggers skeletal muscle contraction by binding to troponin $\mathrm{C}$ and that calcium can be sequestered in the sarcoplasmic reticulum. These studies led to the notion that calcium signals inside cells oscillate: the cytoplasmic calcium concentration increases, a particular effector is activated, and then the calcium signal is reversed to reset the system (see Figs. 1 and 2). Cells use a "toolkit" of channels, pumps, and cytosolic buffers to control calcium levels (Berridge et al. 2000). Numerous proteins are modulated directly or indirectly by calcium. These include kinases and phosphatases, transcription factors such as NF-AT, and the ubiquitous calcium-binding protein calmodulin (CaM).

Electrical, hormonal, and mechanical stimulation of cells can produce calcium signals by causing entry of the ion across the plasma membrane or its release from intracellular stores. Binding of hormones to G-protein-coupled receptors (GPCRs), for example, leads to generation of the second messenger inositol 1,4,5-trisphosphate $\left(\mathrm{IP}_{3}\right)$, which releases calcium from intracellular stores such as the endoplasmic reticulum. By contrast, electrical or neurotransmitter stimulation of neurons causes calcium to enter 
cells from outside via channels in the plasma membrane. This can increase the average cytosolic calcium concentration from around $100 \mathrm{nM}$ to around $1 \mu \mathrm{M}$. Close to an active channel the calcium concentration can reach tens of micromolar. Such local hot-spots of calcium are used by cells to activate specific process that are generally not sensitive to the bulk cytosolic calcium concentration (Bootman et al. 2001).

Cellular calcium signaling proteomes are tissue-specific, producing unique calcium signals that suit a tissue's physiology (Berridge et al. 2003). For example, cardiac myocytes require a rapid (hundreds of milliseconds) wholecell calcium transient to trigger contraction every second (Bers 2002), whereas cells that are not electrically excitable typically display calcium oscillations that last for tens of seconds, and can have a periodicity of several minutes, to control gene expression and metabolism (Dupont et al. 2011). The rapid calcium signals within myocytes are caused by calcium entering through voltage-activated calcium channels in the plasma membrane, which then triggers calcium release via ryanodine receptors on the sarcoplasmic reticulum. The slower calcium signals in nonexcitable cells typically rely on $\mathrm{IP}_{3}$, which binds to channels ( $\mathrm{InsP}_{3-}$ Rs) on the endoplasmic reticulum, or potentially nicotinic acid adenine dinucleotide phosphate-gated calcium channels (two pore channels) on acidic organelles, leading to release of calcium into the cytoplasm (Galione 2011). Calcium signals can also pass through gap junctions to coordinate activities of neighboring cells (Sanderson et al. 1994).

The actions of calcium can be mediated by direct binding of calcium to effectors, such as the phosphatase calci- neurin (Berridge 2006). Alternatively, it can act via the ubiquitous calcium-binding protein CaM. The interaction of calcium with CaM leads to a rearrangement of the protein that allows it to bind and allosterically regulate target molecules such as the calcium/calmodulin-dependent kinases CaMKII and CaMKIV. CaM is mobile within cells and can associate with its targets after binding calcium. However, in some cases, it is prebound to its target, which provides rapid control. Ultimately, calcium signals are reversed by the action of pumps such as the sarco/endoplasmic reticulum ATPases (SERCA) that return it from the cytosol to intracellular stores or the external milieu.

\section{REFERENCES}

Berridge MJ. 2006. Calcium microdomains: Organization and function. Cell Calcium 40: 405-412.

Berridge MJ, Lipp P, Bootman MD. 2000. The versatility and universality of calcium signalling. Nat Rev Mol Cell Biol 1: 11-21.

Berridge MJ, Bootman MD, Roderick HL. 2003. Calcium signalling: Dynamics, homeostasis and remodelling. Nat Rev Mol Cell Biol 4: 517-529.

Bers DM. 2002. Cardiac excitation-contraction coupling. Nature 415: $198-205$

Bootman MD, Lipp P, Berridge MJ. 2001. The organisation and functions of local $\mathrm{Ca}^{2+}$ signals. J Cell Sci 114: 2213-2222.

Carafoli E. 2003. The calcium-signalling saga: Tap water and protein crystals. Nat Rev Mol Cell Biol 4: 326-332.

Dupont G, Combettes L, Bird GS, Putney JW. 2011. Calcium oscillations. Cold Spring Harb Perspect Biol 3: a004226.

Galione A. 2011. NAADP receptors, Cold Spring Harb Perspect Biol 3: a004036.

Sanderson MJ, Charles AC, Boitano S, Dirksen ER. 1994. Mechanisms and function of intercellular calcium signaling. Mol Cell Endocrinol 98: $173-187$ 


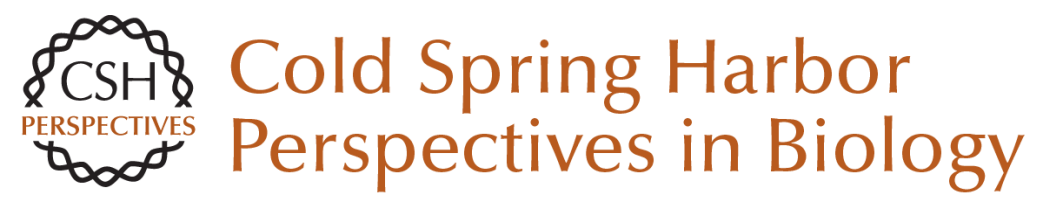

\title{
Calcium Signaling
}

\author{
Martin D. Bootman
}

Cold Spring Harb Perspect Biol 2012; doi: 10.1101/cshperspect.a011171

\section{Subject Collection Signal Transduction}

\section{Cell Signaling and Stress Responses} Gökhan S. Hotamisligil and Roger J. Davis

Protein Regulation in Signal Transduction Michael J. Lee and Michael B. Yaffe

Synaptic Signaling in Learning and Memory Mary B. Kennedy

Vertebrate Reproduction Sally Kornbluth and Rafael Fissore

Signaling in Lymphocyte Activation Doreen Cantrell

Signaling in Muscle Contraction Ivana Y. Kuo and Barbara E. Ehrlich

\section{Toll-Like Receptor Signaling} Kian-Huat Lim and Louis M. Staudt

Signaling Pathways that Regulate Cell Division Nicholas Rhind and Paul Russell
Second Messengers

Alexandra C. Newton, Martin D. Bootman and John D. Scott

\section{Signals and Receptors} Carl-Henrik Heldin, Benson Lu, Ron Evans, et al.

Cell Death Signaling Douglas R. Green and Fabien Llambi

Signaling Networks that Regulate Cell Migration Peter Devreotes and Alan Rick Horwitz

Signaling Networks: Information Flow, Computation, and Decision Making Evren U. Azeloglu and Ravi lyengar

Signal Transduction: From the Atomic Age to the Post-Genomic Era Jeremy Thorner, Tony Hunter, Lewis C. Cantley, et al.

Signaling by the TGF $\beta$ Superfamily Jeffrey L. Wrana

Subversion of Cell Signaling by Pathogens Neal M. Alto and Kim Orth

For additional articles in this collection, see http://cshperspectives.cshlp.org/cgi/collection/

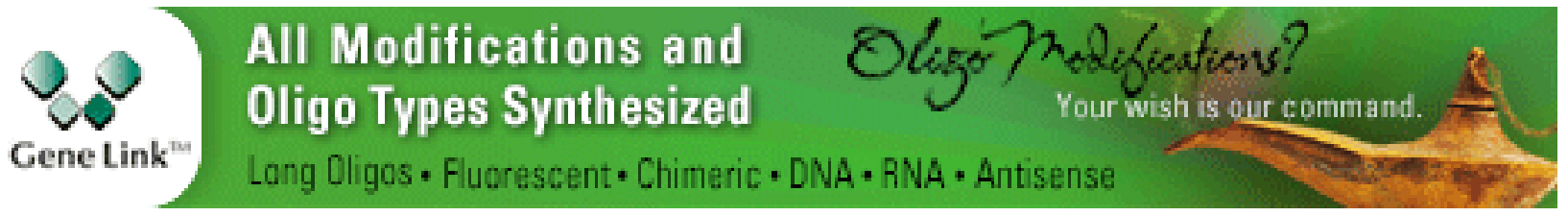

Copyright @ 2012 Cold Spring Harbor Laboratory Press; all rights reserved 